\title{
ORGANOCLORATED AND ORGANOPHOSPHORUS PESTICIDES IN THE PELOTAS RIVER SEDIMENT
}

\author{
Kathleen J. Model ${ }^{1}$, Silvio C. Sampaio ${ }^{2 *}$, Marcelo B. Remor ${ }^{1}$, Erivelto Mercante ${ }^{1}$, Márcio A. Vilas Boas ${ }^{1}$ \\ 2* Corresponding author. Universidade Estadual do Oeste do Paraná/ Cascavel - PR, Brasil. Email: silvio.sampaio@unioeste.br
}

\section{KEYWORDS}

agricultural pesticides, disulfoton, p'p'-DDT.

\begin{abstract}
Aquatic sediments are widely used for the evaluation of anthropogenic contamination due to their ability to adsorb particles and contaminants, making them historical environmental archives. Therefore, the objective was to evaluate the contamination of the Pelotas River sediments, at the border between the states of Santa Catarina and Rio Grande do Sul, by organochlorine and organophosphorus compounds, determining the ecological risk. The evaluation was carried out with quarterly sediment collections in 8 points, totalizing four campaigns within one year, with the aid of the Peterson dredger. Among organochlorines, p'p'DDT stands out regarding environmental persistence, representing $53.23 \%$ of the contaminated samples, with values varying up to $0.158 \mathrm{ppb}$. As for the organophosphates, Methyl Parathion obtained larger representation with 48.4\% of the contaminated samples, with concentrations ranging up to $2.42 \mathrm{ppb}$. The ecological risk of selected organochlorines demonstrated no problems associated with the biota. Regarding the organophosphates studied, Disulfoton presented a risk factor with significant potential for adverse effects on organisms. Therefore, the need for monitoring and sustainability in the use and application of pesticides is well known, aiming at environmental quality and the preservation of natural resources.
\end{abstract}

\section{INTRODUCTION}

The growth of agricultural production was only possible due to the use of pesticides. However, the excessive and unconcerned application has been causing environmental damage. Some pesticides presented acute toxicity, mutagenic, carcinogenic, endocrine disruptor effects, besides being bioaccumulative and persistent. They often enter aquatic systems through percolation, surface runoff or air drift, putting not only the environment but also public health at risk (Gao et al., 2009).

The organochlorine and organophosphate pesticide classes present alarming contamination problems, both in intensity and on a geographic scale. The organochlorines were represented by the use of dichloro-diphenyltrichloroethane (DDT) and its derivatives, which were widely used in the 1960s and 1970s (Girard, 2013). However, given the high environmental persistence and toxicity of organochlorines, their use and commercialization were banned in Brazil in 1985 (BRASIL, 1985). The organophosphorus compounds were developed as an alternative measure, aiming to be less persistent and toxic in the environment. However, this pesticide class is highly toxic, more than organochlorines, and extremely volatile, implying directly the problems of environmental pollution and contamination of the entire biota.

In this context, recent research has focused on the effects of pesticides on organisms such as bivalve molluscs (Souza et al., 2012), fish (Kafilzadeh 2015; Choi et al., 2016; Jürgens et al., 2016), bees (Como et al., 2017), birds (Yohannes, 2017), and humans (Lozano-Paniagua et al., 2016; Rodriguéz et al., 2016). Another research line is related to environmental diagnoses in mangroves ( $\mathrm{Wu}$ et al., 2015), bays (Combi et al., 2014), seas (Ragab et al., 2016; Jin et al., 2017), lakes (Bettinetti et al., 2016; Liu et al., 2016; Yuan et al., 2017), and rivers (Li et al., 2015; Rasmussen et al., 2015; Oliveira et al., 2016; Montuori et al., 2016).

Given the ability to adsorb and store particulates and pollutants, aquatic sediments are the most widely used environmental archives for assessing anthropogenic contamination from the atmosphere, soil, and water. Therefore, they potentiate environmental problems caused by pesticides, chemical agents, toxic residues, nutrients or 
pathogenic microorganisms (Pejman et al., 2015). In this context, the objective was to determine the presence, contamination, and ecological risk by organochlorine and organophosphorus pesticides in the Pelotas River sediment, and thus determine the possible ecological risk of these compounds on biota.

\section{MATERIAL AND METHODS}

\section{Study area}

The Pelotas River is located between the states of Santa Catarina and Rio Grande do Sul (Figure 1A) and is the main tributary of the Uruguay River, forming one of the largest hydrographic basins in southern Brazil. It has a drainage area of $13,227 \mathrm{~km}^{2}$, and the main tributaries are the rivers Lava-Tudo, Pelotinhas, Vacas Gordas, Lajeado dos Portões, Santana, and Bernardo José.

Basin delimitation was performed by means of the Spatial Analysis Tools module, Hydrology tool present in the ArcGIS 10 software, following the methodology of Alves Sobrinho et al. (2010) and Dias et al. (2004). The collection points represented in Figure 1A correspond to six located in the Pelotas River (PEL 00 - PEL 05), and two in tributaries (TRI 01 and TRI 02). Collection point PEL 05 was used as an exudation point and the area of general contribution was determined through this point, which covers all other influence areas for the other points, totaling of $2155.8 \mathrm{~km}^{2}$. Therefore, all research developed took into account only the general coverage area for collection points.
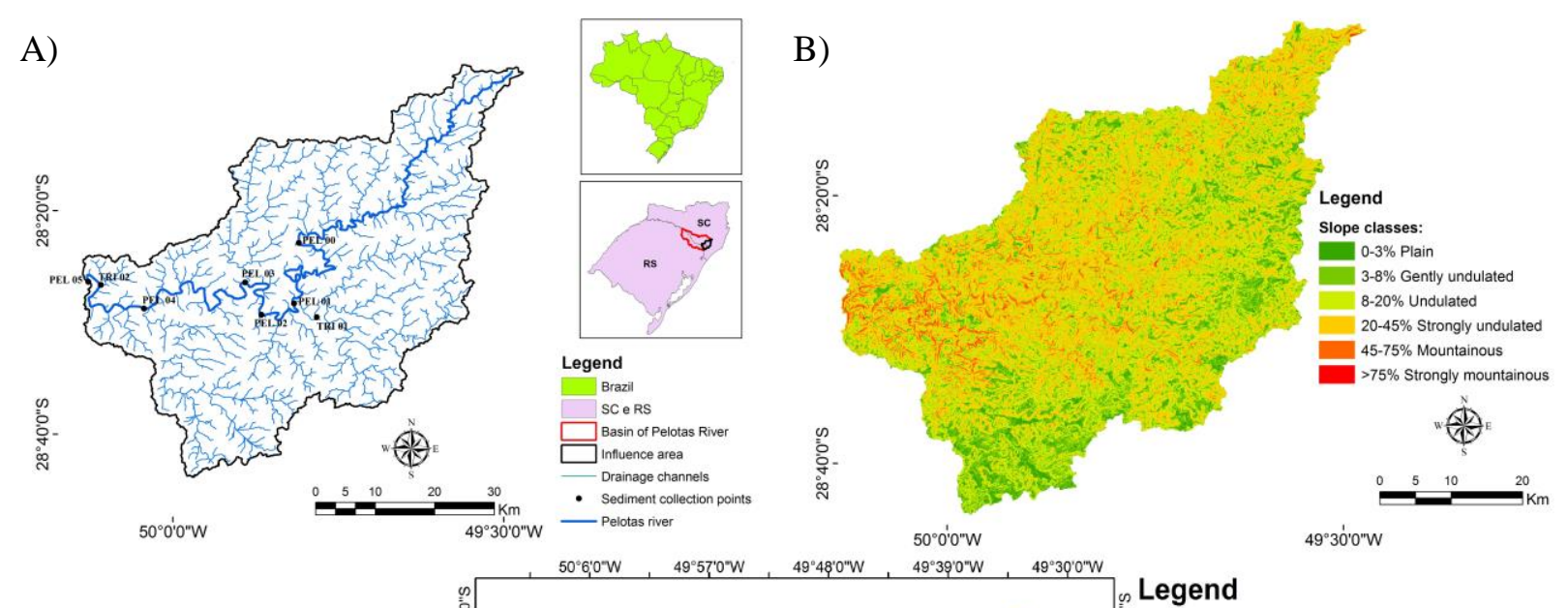

C)
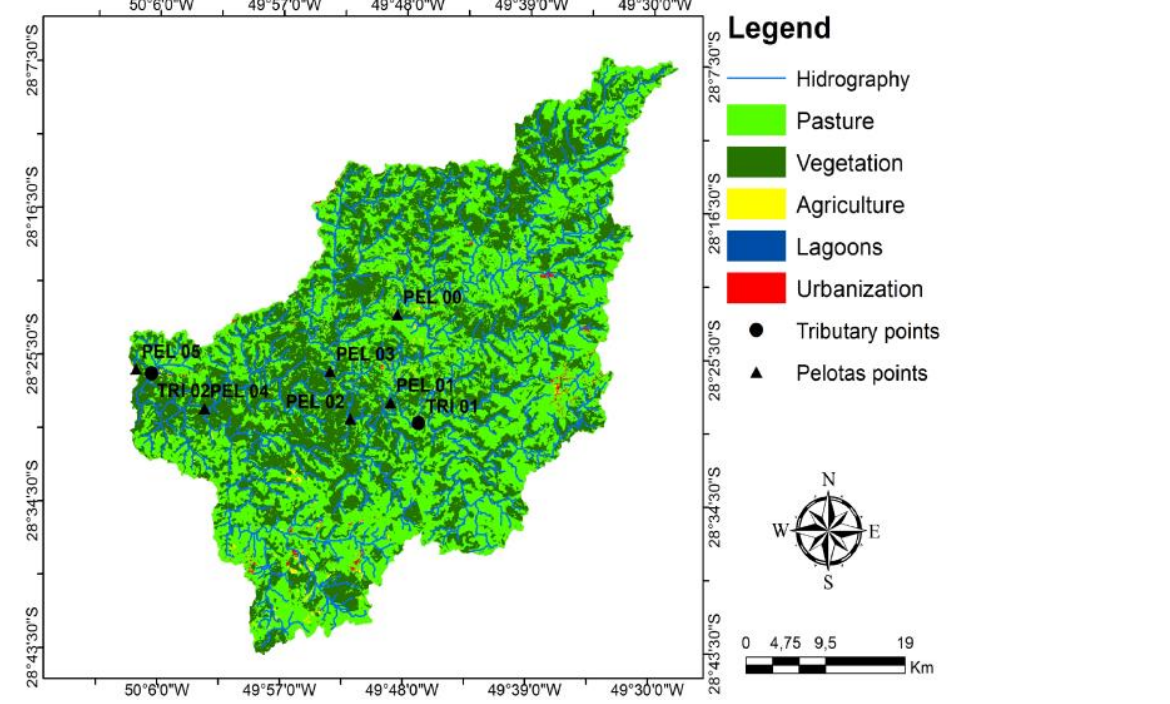

FIGURE 1. Characterization of the study area. A: geographical location; B: terrain slope; C: land use and occupation. by means of the module Spatial Analysis Tools, slope tool present in the software ArcGIS 10 - represented in Figure $1 \mathrm{~B}$, in which the predominance of strong undulating and undulated relief is observed, covering 36,43 and $36.35 \%$ of the entire influence area, respectively. They were followed by gently undulating relief with $17.41 \%$, flat with $5.33 \%$, mountainous with $4.35 \%$, and strongly mountainous with $0.13 \%$. The soils are considered moderately deep and shallow with stoniness, not very fertile and very acidic due to their largely basaltic and sedimentary origin. The hydroelectric potential is evident by the predominant class of the relief (Figure 1B) and by the presence of the Machadinho Hydroelectric Power Plants (UHE) and the Barra Grande Hydroelectric Power Plant.

Grazing areas stood out as the main soil use in the drainage basin $(52.79 \%)$, being followed by vegetation $(45.16 \%)$, agriculture $(0.92 \%)$, and urban areas $(0.46 \%)$, corresponding the total influence area for each point collected. In addition, the basin harbors industrial activities of timber, aper-cellulose, construction, and agroindustrial activities. Soil use and occupation in the drainage basin were determined using the orbital sensor image, dated January 30, 2014, of the Landsat 8 satellite (USGS, 2015). Soil use classification was done in a supervised way, through the algorithm of Maximum Likelihood, present in the plugin Semi-Automatic Classification Plugin (SCP) (Congedo Luca, 2015), of the free software QuantumGIS 2.14.5. Figure $1 \mathrm{C}$ shows the determination of land use and occupation. 


\section{Sample collection and preservation}

The sediment samples were collected with the aid of the Peterson dredger, capable of collecting $0-5 \mathrm{~cm}$ surface sediments with a sample of approximately $2 \mathrm{~kg}$. Five simple samples were collected at each sampling site, constituting a composite sample. The Pelotas river tributaries correspond respectively to TRI 01 - Contas River and TRI 02 - São Sebastião do Arvoredo creek. Table 1 shows the description of the geographical coordinates for each point.

TABLE 1 Geographic coordinates of collection points.

\begin{tabular}{|c|c|c|}
\hline \multirow{2}{*}{$\frac{\text { Points }}{\text { PEL 00 }}$} & \multicolumn{2}{|c|}{ Coordinates } \\
\hline & $28^{\circ} 22^{\prime} 06.7^{\prime \prime} \mathrm{S}$ & $49^{\circ} 47^{\prime} 45.2^{\prime \prime} \mathrm{W}$ \\
\hline PEL 01 & $28^{\circ} 25^{\prime} 54.9^{\prime \prime} \mathrm{S}$ & $49^{\circ} 53^{\prime} 35.5^{\prime \prime} \mathrm{W}$ \\
\hline PEL 02 & $28^{\circ} 26^{\prime} 48.4^{\prime \prime} \mathrm{S}$ & $49^{\circ} 52^{\prime} 57.3^{\prime \prime} \mathrm{W}$ \\
\hline PEL 03 & $28^{\circ} 22^{\prime} 23.8^{\prime \prime} \mathrm{S}$ & $49^{\circ} 59^{\prime} 17.5^{\prime \prime} \mathrm{W}$ \\
\hline PEL 04 & $28^{\prime} 25^{\prime \prime} 42.8^{\prime \prime} \mathrm{S}$ & $50^{\circ} 02^{\prime} 49.3^{\prime \prime} \mathrm{W}$ \\
\hline PEL 05 & $28^{\circ} 24^{\prime} 24.7^{\prime \prime} \mathrm{S}$ & $50^{\circ} 03^{\prime} 37.9^{\prime \prime} \mathrm{W}$ \\
\hline TRI 01 & $28^{\circ} 20^{\prime} 27.4^{\prime \prime} \mathrm{S}$ & $49^{\circ} 48^{\prime} 56.9^{\prime \prime} \mathrm{W}$ \\
\hline TRI 02 & $28^{\circ} 18^{\prime} 50.4^{\prime \prime} \mathrm{S}$ & $49^{\circ} 51^{\prime} 28.0^{\prime \prime} \mathrm{W}$ \\
\hline
\end{tabular}

Samples were conditioned and transported in a refrigerated environment $\left(4^{\circ} \mathrm{C}\right)$ after collection, then dried indoors, protected from the sun, wind, and excessive brightness, at room temperature. Collections took place quarterly, from $05 / 2013$ to $02 / 2014$ following the protocols described by the Environmental Company of the State of São Paulo (CETESB, 2011), and the National Water Agency (ANA, 2011).

TABLE 2. Pesticides analyzed.

\begin{tabular}{|c|c|c|c|}
\hline Compounds & CAS NUMBER & Synonyms & $\begin{array}{l}\mathrm{LD} / \mathrm{LQ} \\
\left(\mathrm{ng} \mathrm{g}^{-1}\right)\end{array}$ \\
\hline & & Organochlorines & $0.02 / 0.03$ \\
\hline Alfa-BHC & $319-84-6$ & Ciclo-hexano; alfa hexachloride benzeno; alfa -Hexachloran; & \\
\hline Gamma-BHC & $58-89-9$ & Hexaclorocicloexano gama-isómero; lindano, & \\
\hline Delta-BHC & $319-86-8$ & delta-Hexaclorociclohexano & \\
\hline Beta-BHC & $319-85-7$ & beta-Hexachloran; beta-Hexaclorobenzeno; beta-lindano & \\
\hline Aldrin & $309-00-2$ & Aldocit; Aldrex; Aldrite; Aldron; Aldrosol; Algran & \\
\hline Dieldrin & $60-57-1$ & 5,8-dimethanonaphthalene; HEOD & \\
\hline Isodrin & $465-73-6$ & Isodrina & \\
\hline Endrin & $72-20-8$ & 5,8-dimethano-naphthalene; exadrin; mendrin & \\
\hline Endrin aldehyde & $7421-93-4$ & Endrina Aldehyde & \\
\hline p'p'-DDT & $50-29-3$ & Clofenotane; p,p'-DDT; parachlorocidum & \\
\hline Methoxychlor & $72-43-5$ & 4-metoxifenil etano; tricloroetano; 4-metoxibenzeno & \\
\hline Dimethanonaphthalene & $15914-93-9$ & Dimethanonaphthalene & \\
\hline Endosulfan I & $115-29-7$ & Crisulfan; cyclodan; devisulfan; endocel; endosol; & \\
\hline Endosulfan sulfate & 1031-07-08 & Sulfato de Endosulfan; 6,7,8,9,10,10-hexacloro-1,5,5a, & \\
\hline Bicyclo(2.2.1)hept-2-ene & 498-66-8 & 2-norborneno, Norbornylene & \\
\hline Heptachlor epoxide & $1024-57-3$ & Heptacloro epóxido; Heptachlor & \\
\hline \multirow[t]{2}{*}{ Delta.lindane } & $58-89-9$ & Hexaclorocicloexano gama-isómero & \\
\hline & & Organophosphates & $0.1 / 0.2$ \\
\hline Dissulfoton & $298-04-4$ & Etilsulfanil & \\
\hline Ronnel Fenchlorphos & $299-84-3$ & Fenclorfos & \\
\hline Methyl parathion & $56-38-2$ & Parathion, 4-nitrofenil & \\
\hline Azinphos-methyl & $86-50-0 ; 54182-73-9$ & Fosforoditioato & \\
\hline Chlorpyrifos & 2921-88-2 & Eradex; Lorsban; Trichlorpyrphos & \\
\hline Ethoprophos & $13194-48-4$ & Mocap; O-etil-S, S-dipropil-fosforoditioato & \\
\hline 2,4-diclorofenol & $120-83-2$ & 2,4-DCP; 4,6-diclorofenol; Diclorofenol, 2,4-DCP; & \\
\hline
\end{tabular}

CAS (American Chemical Society - Chemical Abstract Service); LD (Limit of detection); LQ (Limit of Quantification); The compounds p'p'-DDD and p'p'-DDE are not listed in Table 2, since they are two metabolites of the DDT degradation route, they have no CAS registry, but the two compounds were studied in all samples collected.

\section{Analytical procedures}

According to a World Health Organization recommendation, only the silt + clay fraction $(<63 \mu \mathrm{m})$ of the sediments is used for the determination of micropollutants. This is because this fraction presents greater capacity of cation exchange, and has greater surface area. The gravel and sand fractions $(>63 \mu \mathrm{m})$, on the other hand, end up only diluting contaminated samples and nylon sieve with mesh diameter of $63 \mu \mathrm{m}$.

Pesticide extraction was performed by using the QuEChERS method, described by Fernandes et al. (2013). This technique, which is based on acetonitrile extraction, has proved to be effective when compared to others because it reduces or replaces many of the complex analytical steps in traditional methods. The method provides results with high quality, high yield, low consumption of solvents and glassware, low laboratory expenses, and low cost (Masiá et al., 2015). Analytes were analyzed by gas chromatography coupled with mass spectrometry (Shimadzu, GCMS-QP2010 SE) and separated on capillary column RTX $^{\circledR}-5 \mathrm{MS}$ da Restek ( $30 \mathrm{~m} \times 0.25 \mathrm{~mm} \times 0,25 \mu \mathrm{m})$. The furnace temperature of the column started at $150^{\circ} \mathrm{C}$, increasing up to $300^{\circ} \mathrm{C}$ at the rate of $4^{\circ} \mathrm{C} \min ^{-1}$ and held for $4 \mathrm{~min}$, with a helium entrainment rate of $1.08 \mathrm{~mL} \mathrm{~min}^{-1}$. Ion source temperature of $280^{\circ} \mathrm{C}$, injected volume of $1 \mu \mathrm{L}$, and runtime with gas of $41.50 \mathrm{~min}$. Table 2 describes the organochlorine (OCs) and organophosphates (OFs) pesticides studied. They were identified by comparing the ion retention time with the standard used. (WHO, 1982). Therefore, the sediment was sieved in PVC 


\section{Ecological Risk Assessment}

The possible ecological risks caused by OCs to sediments were compared in two standards. One was the Sediment Quality Guidelines for Aquatic Environments (DQSAA), which states the effects of low range (ELR) and effects of median range (EMR) (Long et al., 1995; Macdonald et al., 1996). In addition, the threshold effect level (TEL) and probable effect level (PEL) provided by the Canadian Council of Ministers of the Environment (CCME, 2002). The levels established by the guidelines delimit the range of probability for adverse biological effects against living organisms.

The assessment of ecological risks caused by OF compounds was based on the ecological risk assessment methodology of the United States Environmental Protection Agency (USEPA), establishing the Risk Quotient (RQ) through the equation (equation 1):

$$
\mathrm{RQ}=\frac{\mathrm{MEC}}{\mathrm{PNEC}}=\frac{\mathrm{MEC}}{\mathrm{LC}_{50} / \mathrm{f}}
$$

In which,

MEC - pesticide concentration detected in the samples;

PNEC - Predicted No Effect Concentration;

$\mathrm{LC}_{50}$ - lethal concentration for $50 \%$ of the population on acute exposure, f - safety factor, determined by the researcher.

The value of 1000 was used, which is the most widely used in the literature.

The definition of $\mathrm{LC}_{50}$ per test organism for each pesticide was determined by data availability in reference bibliographies.

The maximum probable risk was defined using the maximum sample concentration in data interpretation (Cristale et al., 2013). RQ was calculated for the OFs that presented the three highest average concentrations: Methyl Parathion, Disulfoton, and Azinphos-methyl.

\section{RESULTS AND DISCUSSION}

Tables 3 and 4 show the mean concentrations of the pesticides OCs and OFs detected and quantified at the collection points. Compounds OCs alpha-BHC; gammaBHC; beta-BHC; Dieldrin; Endosulfan I; Endosulfan sulfate; Endrin; Endrin aldehyde; and OFs Chlorpyrifos; Ethoprophos; O (2,4-dichlorophenyl) were not detected during the sampling period at any collection point. For the other pesticides, oscillations could be evinced between collections and points; in other words, not all of them were found throughout collections, and the concentrations varied over the sampling period.

TABLE 3. Pesticide concentration at collection points in the Pelotas River ( $\left.\mathrm{ng} \mathrm{g}^{-1}\right)$.

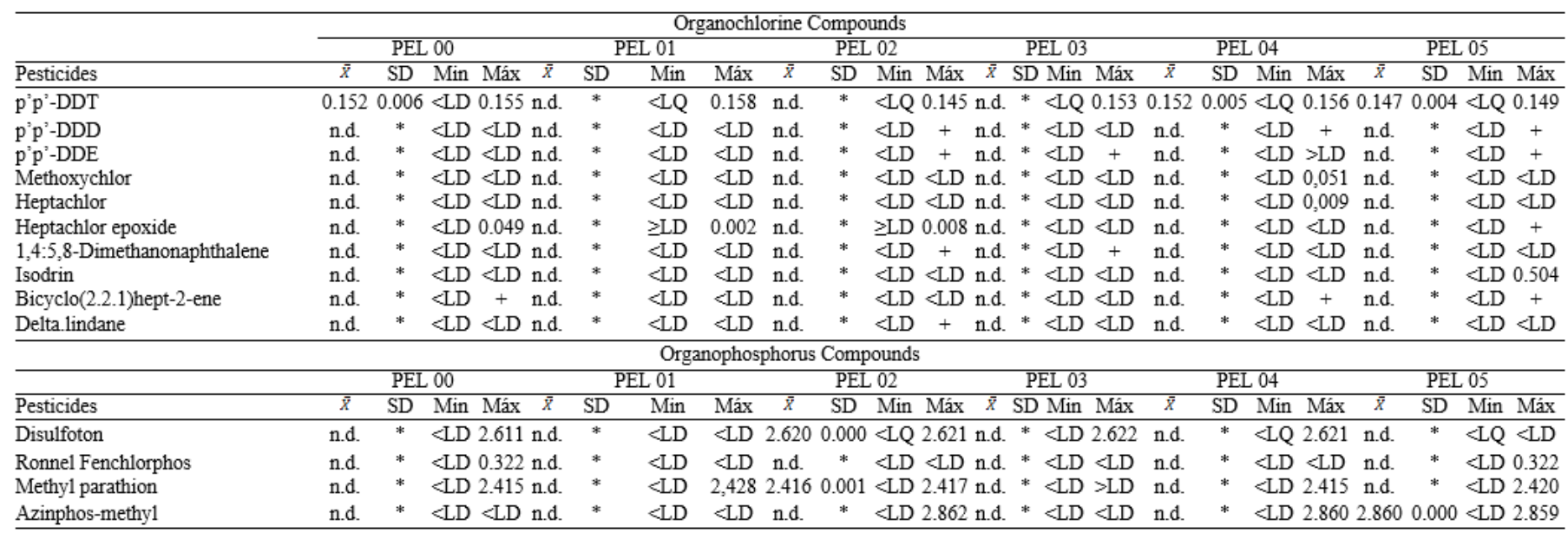

LD (limit of detection); + (> LD and $\leq$ LQ (limit of quantification)); n.d. (not detected); * (not calculated); $\bar{X}$ (mean of the four collections); SD (standard deviation); Min (minimum concentration found); Max (maximum concentration found) PEL 00 - PEL 05 (collection points). 
TABLE 4. Pesticide concentration $\left(\mathrm{ng} \mathrm{g}^{-1}\right)$ in the Pelotas River Tributaries.

\begin{tabular}{|c|c|c|c|c|c|c|c|c|}
\hline \multirow[b]{3}{*}{ Pesticides } & \multicolumn{5}{|c|}{ Organochlorine Compounds } & \\
\hline & \multicolumn{4}{|c|}{ TRI 01} & TRI 02 & & & \\
\hline & $\bar{X}$ & SD & Min & Máx & $\bar{X}$ & SD & Min & Máx \\
\hline p'p'-DDT & n.d. & $*$ & $<\mathrm{LD}$ & 0.153 & 0.148 & 0.008 & $<\mathrm{LQ}$ & 0.154 \\
\hline p'p'-DDD & n.d. & $*$ & $<\mathrm{LD}$ & $<\mathrm{LD}$ & n.d. & $*$ & $<\mathrm{LD}$ & + \\
\hline p'p'-DDE & n.d. & $*$ & $<\mathrm{LD}$ & + & n.d. & $*$ & $<\mathrm{LD}$ & $<\mathrm{LD}$ \\
\hline Methoxychlor & n.d. & $*$ & $<\mathrm{LD}$ & $<\mathrm{LD}$ & n.d. & $*$ & $<\mathrm{LD}$ & 0.051 \\
\hline Heptachlor & n.d. & $*$ & $<\mathrm{LD}$ & 0.009 & n.d. & $*$ & $<\mathrm{LD}$ & 0.008 \\
\hline Heptachlor epoxide & n.d. & $*$ & $<\mathrm{LD}$ & $<\mathrm{LD}$ & n.d. & $*$ & $\geq \mathrm{LD}$ & 0.002 \\
\hline 1,4:5,8-Dimethanonaphthalene & n.d. & $*$ & $<\mathrm{LD}$ & $<\mathrm{LD}$ & n.d. & $*$ & $<\mathrm{LD}$ & + \\
\hline Isodrin & n.d. & $*$ & $<\mathrm{LD}$ & $<\mathrm{LD}$ & n.d. & $*$ & $<\mathrm{LD}$ & 0.266 \\
\hline Bicyclo(2.2.1)hept-2-ene & n.d. & $*$ & $<\mathrm{LD}$ & $<\mathrm{LD}$ & n.d. & $*$ & $<\mathrm{LD}$ & + \\
\hline Delta.lindane & n.d. & $*$ & $<\mathrm{LD}$ & $<\mathrm{LD}$ & n.d. & $*$ & $<\mathrm{LD}$ & $<\mathrm{LD}$ \\
\hline \multicolumn{9}{|c|}{ Organophosphorus Compounds } \\
\hline & \multicolumn{4}{|c|}{ TRI 01} & \multicolumn{4}{|c|}{ TRI 02} \\
\hline Pesticides & $\overline{\bar{X}}$ & SD & Min & Máx & $\overline{\bar{X}}$ & SD & Min & Máx \\
\hline Disulfoton & n.d. & $*$ & $<\mathrm{LD}$ & $<\mathrm{LD}$ & n.d. & $*$ & $<\mathrm{LD}$ & $<\mathrm{LD}$ \\
\hline Ronnel Fenchlorphos & n.d. & $*$ & $<\mathrm{LD}$ & 0.322 & n.d. & $*$ & $<\mathrm{LD}$ & 0.322 \\
\hline Methyl parathion & 2.419 & 0.006 & $<\mathrm{LD}$ & 2.422 & n.d. & $*$ & $<\mathrm{LD}$ & $<\mathrm{LD}$ \\
\hline Azinphos-methyl & n.d. & $*$ & $<\mathrm{LD}$ & $<\mathrm{LD}$ & n.d. & $*$ & $<\mathrm{LD}$ & $<\mathrm{LD}$ \\
\hline
\end{tabular}

LD (limit of detection); + (> LD and $\leq$ LQ (limit of quantification)); n.d. (not detected); * (not calculated); (mean of the four collections); SD (standard deviation); Min (minimum concentration found); Max (maximum concentration found) TR I01 - TRI 02 (collection points).

\section{Pesticides OCs in sediment samples}

The compounds OCs, p'p'-DDD, p'p'-DDE, 1,4: 5,8-Dimethanonaphthalene, Bicyclo (2.2.1) hept-2-ene had concentrations higher than or equal to $\mathrm{LD}$, or lower than LQ, at virtually all collection points.

Among the pesticides found, p'p'-DDT deserves to be highlighted, as it was found in the four collections and was present in $53.23 \%$ of the OCs contaminated samples, with concentrations ranging from $\angle \mathrm{LD}$ to $0.158 \mathrm{ng} \mathrm{g}^{-1}$. The highest representativeness was at point PEL 01, which was the point that also presented the highest concentration with $0.158 \mathrm{ng}^{-1}$. There are two explanations for the high detection frequency of p'p'-DDT in the sediment. First, because the OCs are pesticides with a high degree of bioaccumulation and environmental persistence (Baird \& Cann, 2011), therefore they are still found at significant concentrations in the environment. In addition, through chemical and biological processes, the DDT in the environment can be converted into DDD, DDE, and DDA; that is why in many environments, DDE concentrations are higher than that of DDT (Bosch et al., 2015).

The concentrations of the different compounds derived from DDT can be related to the degradation time (Pandit et al., 2002) and the contamination period. The DDT/(DDE+DDD) ratio is used for this, and a quotient higher than 0.5 indicates recent DDT contamination, whereas values below 0.5 indicate an earlier contamination, as highlighted in the research by $\mathrm{Wu}$ et al., (2013); Hijosa-Valsero et al. (2016); Oliveira et al. (2016).

Only p'p'-DDD and p'p'-DDE pesticides were found in this study, therefore, a relationship cannot be established. However, there is evidence that the contamination in the influence area may have been recent, since DDT presence indicates constant entry into the environment, i.e., as concentrations of p'p'-DDT and only the presence of its metabolites were found, there is evidence of possible recent entry of this compound, since its half-life is approximately eight years. In addition, DDT is used in the formulations of other pesticides with restricted amounts, such as Dicofol, an acaricide used in several types of crops, which may also indicate recent entry into the environment ( $\mathrm{Li}$ et al., 2015; Wu et al., 2015).

Isodrin, which is considered an isomer of Aldrin, was present in $23.53 \%$ of the total OCs samples, with values ranging from $<\mathrm{LD}$ up to $0.504 \mathrm{ng} \mathrm{g}^{-1}$. This was the compound with the highest concentration of all the OCs and is represented by points PEL05 and TRI02, which had the highest percentages of agricultural area (0.97 and $2.63 \%$, respectively) and higher slope degrees (mountainous and strongly mountainous), which may have contributed to the concentrations of this compound.

The insecticide methoxychlor was identified in a sample of the PEL 04 and one of TRI 02, and the concentration found at both points was $0.511 \mathrm{ng} \mathrm{g}^{-1}$. Heptachlor epoxide is a metabolite of heptachlor and considered more toxic than its original compound. In addition, both are insoluble in water, resulting in higher sediment concentrations and organism bioaccumulation (Fenoglio et al., 2009). Heptachlor was found at points PEL 04, TRI 01, and TRI 02, with a maximum concentration of $0.009 \mathrm{ng} \mathrm{g}^{-1}$. Heptachlor epoxide had higher concentrations when compared to its original compound at points PEL 00, PEL 01, and PEL 02, from 0.001 to $0.04 \mathrm{ng} \mathrm{g}^{-1}$. The highest concentration was represented by point PEL 00, which can be explained by the slope degree of the soil present at this collection site, which is considered mountainous and strongly mountainous.

Considering that the commercialization, use, and distribution of OCs compounds have been banned in Brazil since 1985 by decree no. 329 (BRASIL, 1985), the presence of OCs in the Pelotas River sediment could be 
explained by some hypotheses. Farmers who had obtained these pesticides prior to the ban continued to use products that were stocked on their properties and/or disposed of packages improperly, causing these pesticides to percolate down to rivers, seas, groundwater, among others. Thus, due to the persistence and bioaccumulation properties of these compounds, they are still present in representative concentrations in the soils, being carried via surface runoff to the river, where they are sedimented in low energy environments. The other hypothesis is the commercialization of OCs via parallel trade, a hypothesis that is based on numerous apprehensions made by the police in control actions.

The disparity of the OCs compounds concentrations found in the Pelotas River sediment may be due to the contribution of different sources, altering the deposition dynamics in the watercourse. The OCs can come from the wind transport of regions where there is an application or by the hydrological river cycle in which deposition of fine sediments takes place in the dry season. The washing of this material in the rains and the very movement that occurs inside the river, as natural sedimentation and resuspension movements, directly influence the bioavailability of these compounds. The compounds can also be transported at the water column/sediment interface, along with iron and manganese mineral oxides, carbonates, and organic matter (Pejman et al., 2015).

The high slope of the terrain directly influences compound concentrations, since it assists in the transport of these particles. Thus, concentrations tend to be higher in sites with a steep slope, as was the case of points PEL 04, PEL 05, and TRI 02. These points are also representative of the sites with the highest percentages of agricultural areas in the entire study area, corresponding to $0.93,0.97$, and $2.63 \%$, respectively, which justifies the higher concentrations of OCs found in the study.

Table 5 shows the comparison of the results found in this study with others found in the literature. It is worth highlighting that each fluvial environment has its peculiar characteristics. In this way, the concentrations of pollutants vary according to the environmental characteristics to which they are exposed, such as the internal conditions of the river itself (hydrological cycle, resuspension phenomena, deposition, $\mathrm{pH}$, among others), and the external conditions imposed by the environment (precipitation, temperature, erosion, leaching).

TABLE 5. Concentration of pesticides in sediments of fluvial environments.

\begin{tabular}{|c|c|c|c|c|}
\hline & \multicolumn{4}{|c|}{ Organochlorines $\left(\right.$ ng g $\left.^{-1}\right)$} \\
\hline & p'p'-DDT & Metoxychlor & Heptachlor & Heptachlor epoxide \\
\hline \multicolumn{5}{|l|}{ Aquatic enviroments } \\
\hline Pelotas river* & 0.160 & 0.050 & 0.009 & 0.049 \\
\hline Jaguaribe river (Brazil)(Oliveira et al., 2016) & 0.98 & nd & 14.84 & nd \\
\hline Yellow river (China) (Li et al., 2015) & 11.13 & NA & NA & NA \\
\hline Daling river (China) (Wang et al., 2013) & 3 & NA & 0.65 & 0.52 \\
\hline Scheldt river (Belgium)(Covaci et al., 2005) & 7.9 & NA & NA & NA \\
\hline Yangtze estuary (China) (Liu et al., 2008) & 2.5 & NA & NA & NA \\
\hline Pearl river delta (China) (Fung et al., 2005) & 145.57 & NA & 17.7 & 5,6 \\
\hline Atoya river (Nicaragua) (Castilho et al., 2000) & 95.5 & NA & nd & NA \\
\hline Danúbio river delta (Romania) (Covaci et al., 2006) & 0.8 & NA & NA & NA \\
\hline Densu river (Ghana) (Kuranchie-Mensah et al., 2012) & 0.18 & 0.11 & 0.68 & NA \\
\hline Arc river (France) (Kanzari et al., 2012) & 1.24 & NA & NA & NA \\
\hline Cascavel river (Brazil) (Cembranel et al., 2017) & 0,398 & 1,411 & 0,038 & 1,014 \\
\hline
\end{tabular}

*This study; n.d. (not detected in the literature cited); NA (not analyzed).

\section{OFs pesticides in sediment samples}

The most representative compound in the OFs research is Chlorpyrifos, which was not found in the study. Of the seven pesticides of this class, four were found, as shown in Table 4. Among the compounds studied, Methyl parathion had greater representativeness, especially PEL 02 and TRI 01, which presented the highest

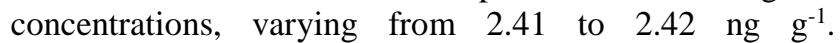
Azinphos-methyl, in turn, had concentrations ranging from 2.85 to $2.86 \mathrm{ng} \mathrm{g}^{-1}$, while Disulfoton, used to control mites and insects, was found at points PEL 00, PEL 02, PEL 03, and PEL 04, at concentrations ranging from 2.61 to 2.62 $\mathrm{ng} \mathrm{g}^{-1}$. The points PEL 02, PEL 04, and PEL 05 had the highest OFs concentrations. The representativeness of the points PEL 04 and PEL 05 can be explained by the percentages of agricultural area corresponding, respectively, to 0.93 and $0.97 \%$ of the total study area. PEL 02 covers $0.66 \%$ of the agricultural activity with classified declivity, within the scope of its influence area, classified as strongly mountainous, which can contribute to the transportation of pollutants. These points also had the highest CBs values, indicating areas of greater need for research, control, and intervention.

The same justifications mentioned for the CBs can be inferred here, as there are disparity and low concentrations among the points and the collections. However, it should be noted that the volatility characteristic of these compounds, which is significant, facilitates their atmospheric dispersion since the vast majority of these pesticides are applied via aerosol. This particularity of the OFs can be used to explain the nonrepresentativeness of the collection points, and this category shows a greater distribution of the concentrations between the eight collection points.

Although the concentrations found can be considered relatively low, it is worth remembering that many of these compounds have high toxicity, even when compared to some OCs. This characteristic is explained by the liposolubility of these pesticides, which allows them to be absorbed directly by almost all direct contact pathways, such as skin and mucous membranes. In addition, it is also due to their ability to inactivate the enzyme 
acetylcholinesterase (acetyl CoA), causing central nervous system depletion in humans (Baird \& Cann, 2011).

\section{World reference values for pesticide concentration}

The concentrations of the pesticides OCs and OFs studied were compared to global reference values established by surveillance agencies shown in Table 6 . The results obtained in the Pelotas River were not compared with Brazilian legislation, since the only guideline values derive from the Brazilian National Environment Council (CONAMA) for pesticides in dredged sediments, CONAMA number 344 of 2004 and 454 of 2012, for water CONAMA 23 of 1996, 357 of 2005 and 420 of 2009 and soil, CONAMA 420 of 2009.
When compared to those found in the Pelotas River, there is a discrepancy only with the reference values established by the Van Volkshuisvesting Ruimtelijke Ordening en Milieubeheer (VROM), from the Netherlands, for Heptachlor epoxide (OC) and Azinphosmethyl (OF). The reference concentrations should vary with the region; in some places, they can be considered low, or cause undesirable effects on the biota and humans in others. Therefore, several factors directly influence the concentration and bioavailability of these pollutants. Among these factors are the environmental conditions, physicochemical characteristics of compounds, and the composition of adsorbed-material to the particle and, in sediment studies, texture, concentrations of oxides, organic matter, and carbon.

TABLE 6. Limits established for pesticide concentrations $\left(\mathrm{ng} \mathrm{g}^{-1}\right)$ in sediments of fluvial environments.

\begin{tabular}{lllll}
\hline & \multicolumn{3}{c}{ Organochlorines } \\
\hline Pesticides & DEC & CCME & VROM & Pelotas river (concentration range) \\
\hline p'p'-DDT & 1.6 & 1.19 & $*$ & LD - 0.16 \\
p'p'-DDD & 2 & 3.54 & $*$ & LD - LQ \\
p'p'-DDE & 2.2 & 1.42 & $*$ & LD - LQ \\
Methoxychlor & $*$ & $*$ & $*$ & LD - 0.05 \\
Heptachlor & $*$ & 0.6 & 0.7 & LD - 0.009 \\
Heptachlor epoxide & $*$ & 0.6 & 0.0002 & LD - 0.049 \\
1,4:5,8-Dimethanonaphthalene & $*$ & $*$ & $*$ & LD - LQ \\
Isodrin & $*$ & 2.67 & $*$ & LD - 0.503 \\
Bicyclo(2.2.1)hept-2-ene & $*$ & $*$ & $*$ & LD - LQ \\
Delta.lindane & 0.32 & 0.94 & $*$ & LD - LQ \\
\hline & & & Organophosphates & \\
\hline Disulfoton & $*$ & $*$ & $*$ & LD - 2.621 \\
Ronnel Fenchlorphos & $*$ & $*$ & $*$ & LD - 0.322 \\
Methyl parathion & $*$ & $*$ & $*$ & LD - 2.862 \\
Azinphos-methyl & $*$ & $*$ & 0.05 & . \\
\hline
\end{tabular}

DEC (Department of the Environment and Conservation, 2010, Australia); CCME (Canadian Council of Ministers of the Environment, 2002, Canada); VROM (Ministerie Van Volkshuisvesting Ruimtelijke Ordening en Milieubeheer, 2000, The Netherlands); * (Parameter not available - exempt from analysis).

\section{Ecological risk assessment}

Table 7 shows the ecological risk assessment for OCs compounds, which was elaborated taking into consideration the pesticides that are available for evaluation in the DQSAA, also used by the researchers Barakat et al. (2012); Barakat et al. (2013); Wu et al., (2013); Li et al., (2015); Oliveira et al. (2016). The compound with the greatest variation in concentrations was p'p'-DDT, but in none of the evaluations, the values exceeded or even approached the value of TEL, indicating that adverse effects will rarely occur. The same occurred for the compound Heptachlor epoxide, with values lower than TEL (Table 7).

TABLE 7. Ecological risk assessment for OCs compounds from the Pelotas River basin sediment.

\begin{tabular}{|c|c|c|c|c|c|}
\hline Pesticides & Concentration range $\left(\right.$ ng. $\left.^{-1}\right)$ & $\begin{array}{l}\text { TEL } \\
\left.\text { (ng. } \text { g }^{-1}\right)\end{array}$ & $\begin{array}{l}\text { PEL } \\
\left.\text { (ng. } \text {. }^{-1}\right)\end{array}$ & $\begin{array}{l}\text { ERL } \\
\left(\text { ng. } g^{-1}\right)\end{array}$ & $\begin{array}{l}\text { ERM } \\
\left.\text { (ng. } g^{-1}\right)\end{array}$ \\
\hline Heptachlor epoxide & n.d. $-0,05$ & 0,6 & 2,74 & s.r. & s.r. \\
\hline$p^{\prime}, p^{\prime}-D D E$ & n.d. - n.q & 2,07 & 374 & 2,2 & 27 \\
\hline p',p'-DDD & n.d. - n.q & 1,22 & 7,81 & 2 & 20 \\
\hline p',p'-DDT & n.d. $-0,15$ & 1,19 & 4,77 & 1 & 7 \\
\hline
\end{tabular}

n.d. (not detected); s.r. (no reference); n.q (not quantified) TEL (threshold effect level); PEL (probable effect level) (CCME, 2002); ERL (effect low range); ERM (effect median range) (Long et al., 1995; Macdonald et al., 1996); considering: <ERL (adverse effects will rarely occur); $\geq$ ERL and $<$ ERM (adverse effects will occasionally occur); $<$ TEL (minimum level effect on biota); $\geq$ TEL and $\leq$ PEL (adverse effects will occasionally occur); > PEL (adverse effects will frequently occur). 
The metabolites of DDT, p',p'-DDE, and p',p'DDD were not detected $(<\mathrm{LD})$ or showed concentrations below the quantification index $(>\mathrm{LD}$ or $\leq \mathrm{LQ})$ in all samples, with no ecological risk (Long et al., 1995; Macdonald et al., 1996; CCME, 2002). The p ', p'-DDT, even below the TEL, was quantified in at least one sample at each of the sampling points, totaling 12 quantified samples, but at concentrations lower than ERL, in which adverse damages are rarely observed.

Table 8 shows the ecological risk for OFs compounds, and has already been developed in the studies carried out by the Cristale et al. (2013); Chen et al. (2014); Selvaraj et al. (2014); Ccanccapa et al. (2016); Montuori et al. (2016).

TABLE 8. Ecological risk assessment for OFs compounds from the Pelotas River basin sediment.

\begin{tabular}{lccc}
\hline Pesticides & Concentration range $\left(\right.$ ng.g $\left.^{-1}\right)$ & LC $_{50}\left(\right.$ ng.g $\left.^{-1}\right)$ & RQ (for maximum concentration) \\
\hline Methyl Parathion & n.d. -2.42 & $6900^{\mathrm{a}}$ & 0.35 \\
Disulfoton & n.d. -2.62 & $240^{\mathrm{b}}$ & 10.92 \\
Azinphos-methyl & n.d. -2.86 & $21800^{\mathrm{c}}$ & 0.13 \\
\hline
\end{tabular}

n.d. (not detected); RQ = MEC (ng. $\left.\mathrm{g}^{-1}\right) / \mathrm{LC}_{50} / \mathrm{f} ;{ }^{\mathrm{a}} \mathrm{LC}_{50}$ on H. azteca (Weston et al., 2013); ${ }^{\mathrm{b}} \mathrm{LC}_{50}$ on G. lacustres(ECOTOX); ${ }^{\mathrm{c}} \mathrm{LC} 50$ on $A$. tenuiremis (Klosterhaus et al., 2003); considering: $\mathrm{RQ}<1.0$ (there is no significant risk on biota); $1.0 \leq \mathrm{RQ}<10$ (small potential for adverse effects on biota); $10 \leq \mathrm{RQ}<100$ (significant potential for adverse effects on biota); RQ $\geq 100$ (potential adverse effects on biota to be expected).

The maximum concentrations of the pesticides Methyl Parathion and Azinphos-methyl pose no significant risk to organisms in benthic environments, as they have a coefficient of $<1$. However, the maximum concentration of the pesticide Disulfoton indicates a risk coefficient with a significant potential for adverse effects on aquatic organisms. At all collection points, five samples had concentrations at the same risk situation, and the compound was not detected in the others.

Considering the increase in the intoxication of people with the unrestrained use of agrochemicals together with the dispersion and persistence capacity of many compounds, we emphasize the need for greater investment and focus on the control of the use of these chemical agents, besides the development of studies that infer the environmental situation as a whole. Along with all these factors, we can mention the need for producers' awareness and environmental education practices. Additionally, some artifacts should be used to bring scientific information out of academia, being delivered to all social classes, so that pesticide use could be improved as a whole, aiming at a safe and secure food production for the benefit of animal and human health.

\section{CONCLUSIONS}

Of the 24 pesticides analyzed, only the organophosphate Disulfoton presents Ecological Risk in the study area. However, although p'p'-DDT has low concentrations in the sediment, it stands out due to the high environmental persistence and possible recent contamination of this compound, since only the presence of its metabolites was found. The most representative contamination points for both classes studied were PEL 05 and TRI 02.

\section{ACKNOWLEDGEMENTS}

The authors acknowledge the financial support of the National Council for Scientific and Technological Development (CNPq), the Coordination for the Improvement of Higher Education Personnel (CAPES), the State University of Western Paraná (UNIOESTE), and the Agricultural Engineering Postgraduate Program (PGEAGRI).

\section{REFERENCES}

Alves Sobrinho T, Oliveira PTS, Rodrigues, DBB, Ayres MF (2010) Delimitação automática de bacias hidrográficas utilizando dados SRTM. Engenharia Agrícola 30(1):4657.

Baird C, Cann M (2011) Química Ambiental. Porto Alegre, Bookman, 4 ed. 844p.

Barakat AO, Khairy M, Aukaily I (2013) Persistent organochlorine pesticide and PCB residues in surface sediments of Lake Qarun, a protected area of Egypt. Chemosphere 90(9):2467-2476. DOI:

http://dx.doi.org/10.1016/j.chemosphere.2012.11.012

Barakat AO, Mostafa A, Wade TL, Sweet ST, El Sayed NB (2012) Spatial distribution and temporal trends of persistent organochlorine pollutants in sediments from Lake Maryut, Alexandria, Egypt. Marine Pollution Bulletin 64(2):395-404. DOI: https://dx.doi.org/10.1016/j.marpolbul.2011.12.019

Bettinetti R, Quadroni S, Boggio E, Galassi S (2016) Recent DDT and PCB contamination in the sediment and biota of the Como Bay (Lake Como, Italy). Science of The Total Environment 542(A):404-410. DOI: http://dx.doi.org/10.1016/j.scitotenv.2015.10.099

Bosch C, Grimalt JO, Fernández P (2015) Enantiomeric fraction and isomeric composition to assess sources of DDT residues in soils. Chemosphere 138:40-46. DOI: https://dx.doi.org/10.1016/j.chemosphere.2015.05.047

BRASIL (1985) Ministério da Agricultura. Portaria no 329.

Castilho JAA, Fenzl N, Guillen SM, Nascimento FS (2000) Organochlorine and organophosphorus pesticide residues in the Atoya river basin, Chinandega, Nicaragua. Environmental Pollution 110(3):523-533. DOI: http://dx.doi.org/10.1016/S0269-7491(99)00277-8

Ccanccapa A, Masiá A, Andreu V, Picó Y (2016) Spatiotemporal patterns of pesticide residues in the Turia and Júcar Rivers (Spain). Science of the Total Environment 540:200-210. DOI:

http://dx.doi.org/10.1016/j.scitotenv.2015.06.063 
CCME - Canadian Council of Ministers of the

Environment (2002) Canadian sediment quality guidelines for the protection of aquatic life. Canadian Environmental Quality Guidelines. Canadian Council of Ministers of the Environment.

Cembranel, AS, Frigo, EP, Sampaio, SC, Mercante, E, Reis, RRDR, Remor, MB (2017) Residue analysis of organochlorine and organophosphorus pesticides in urban lake sediments. Engenharia Agrícola 37:1254-1267. DOI: http://dx.doi.org/10.1590/1809-4430-

Eng.Agric.v37n6p1254-1267/2017

CETESB - Companhia Ambiental do Estado de São Paulo, ANA - Agência Nacional das Águas (2011) Guia nacional de coleta e preservação de amostras: água, sedimento, comunidades aquáticas e efluentes líquidos. CETESB, $326 \mathrm{p}$.

Chen R, Yin P, Zhao L, Yu Q, Hong A, Duan S (2014) Spatial-temporal distribution and potential ecological risk assessment of nonylphenol and octylphenol in riverine outlets of Pearl River Delta, China. Journal of Environmental Sciences 26(11):2340-2347. DOI: http://dx.doi.org/10.1016/j.jes.2014.09.019

Choi M, Lee IS, Jung RH (2016) Rapid determination of organochlorine pesticides in fish using selective pressurized liquid extraction and gas chromatographymass spectrometry. Food Chemistry 205:1-8. DOI: http://dx.doi.org/10.1016/j.foodchem.2016.02.156

Combi T, Taniguchi S, Figueira RCL, Mahiques MMD, Martins CC (2014) Spatial distribution and historical input of polychlorinated biphenyls (PCBs) and organochlorine pesticides (OCPs) in sediments from a subtropical estuary (Guaratuba Bay, SW Atlantic). Marine Pollution Bulletin 70(1-2):247-252. DOI:

http://dx.doi.org/10.1016/j.marpolbul.2013.02.022

Como F, Carnesecchi E, Volani S, Dorni JL, Richardson J, Bassan A, Pavan M, Benfenati E (2017) Predicting acute contact toxicity of pesticides in honeybees (Apis mellifera) through a k-nearest neighbor model. Chemosphere 166:438-444. DOI:

http://dx.doi.org/10.1016/j.chemosphere.2016.09.092

Congedo Luca (2015) Semi-automatic classification plugin documentation. Available:

http://semiautomaticclassificationmanual-

v3.readthedocs.org/en/latest/. Accessed: Nov 22, 2016.

Covaci A, Gheorghe A, Hulea O, Schepens P (2006)

Levels and distribution of organochlorine pesticides, polychlorinated biphenyls and polybrominated diphenyl ethers in sediments and biota from the Danube Delta, Romania. Environmental Pollution 140(1):136-149. DOI: http://dx.doi.org/10.1016/j.envpol.2005.06.008

Covaci A, Gheorghe A, Voorspoels S, Maeyoet J, Redeker ES, Blust R, Schepens P (2005) Polybrominated diphenyl ethers, polychlorinated biphenyls and organochlorine pesticides in sediment cores from the Western Scheldt river (Belgium): analytical aspects and depth profiles. Environment International 31(3):367-375. DOI: http://dx.doi.org/10.1016/j.envint.2004.08.009
Cristale J, Vázquez AG, Barata C, Lacorte C (2013) Priority and emerging flame retardants in rivers: Occurrence in water and sediment, Daphnia magna toxicity and risk assessment. Journal Environment International 59:232-243. DOI: http://dx.doi.org/10.1016/j.envint.2013.06.011

DEC - Departament of Enviroment and Conservation (2010) Contaminated sites management series. Assessment levels for Soil, Sediment and Water.

Dias DOSL, Rocha GA, Barros EUA, Maia PHP (2004)

Utilização do radar interferométrico para delimitação automática de bacias hidrográficas Bahia Análise \& Dados 14(2):265-271.

ECOTOX. Ecotox Knowledgebase. Available: https://cfpub.epa.gov/ecotox/. Accessed: Oct 12, 2016.

Fenoglio C, Grosso A, Boncompagni E, Gandini C, Milanesi G, Barni S (2009) Exposure to heptachlor: Evaluation of the effects on the larval and adult epidermis of Rana kl. Esculenta. Aquatic Toxicology 91(2):151-160. DOI: http://dx.doi.org/10.1016/j.aquatox.2008.07.005

Fernandes VC, Domingues VF, Mateus N, Delerue-Matos CJ (2013) Multiresidue pesticides analysis in soils using modified QuEChERS with disposable pipette extraction and dispersive solid-phase extraction. Journal Separation Science 36:376-382. DOI: http://dx.doi.org/ 10.1002/jssc. 201200673

Fung CN, Zheng GJ, Connell DW, Zhang X, Wong HL, Giesy JP, Fang, Z, Lam PKS (2005) Risks posed by trace organic contaminants in coastal sediments in the Pearl River Delta, China. Marine Pollution Bulletin 50(10):1036-1049. DOI: http://dx.doi.org/10.1016/j.marpolbul.2005.02.040

Gao J, Liu L, Liu X, Zhou H, Lu J, Huang S, Wang Z (2009) The Occurrence and Spatial Distribution of Organophosphorous Pesticides in Chinese Surface Water. Bulletin of Environmental Contamination and Toxicology 82(2):223-229. DOI: http://dx.doi.org/10.1007/s00128008-9618-z

Girard J (2013) Princípios da química ambiental. Tradução de MJ Oliveira. Rio de Janeiro, LTC.

Hijosa-Valsero M, Bécares E, Fernández-Aláez C, Fernández-Aláez M, Mayo R, Jiménez JJ (2016) Chemical pollution in inland shallow lakes in the Mediterranean region (NW Spain): PAHs, insecticides and herbicides in water and sediments. Science of the Total Environment 544:797-810. DOI:

http://dx.doi.org/10.1016/j.scitotenv.2015.11.160

Jin M, Fu J, Xue B, Zhou S, Zhang L, Li A (2017) Distribution and enantiomeric profiles of organochlorine pesticides in surface sediments from the Bering Sea, Chukchi Sea and adjacent Arctic áreas. Environmental Pollution 222:109-117. DOI:

http://dx.doi.org/10.1016/j.envpol.2016.12.075

Jürgens MD, Crosse J, Hamilton PB, Jhonson AC, Jones KC (2016) The long shadow of our chemical past e High DDT concentrations in fish near a former agrochemicals factory in England. Chemosphere 162:333-344. DOI: http://dx.doi.org/10.1016/j.chemosphere.2016.07.078 
Kafilzadeh F (2015) Assessment of Organochlorine Pesticide Residues in Water, Sediments and Fish from Lake Tashk, Iran. Achievements in the Life Sciences 9(2):107-111. DOI:

http://dx.doi.org/10.1016/j.als.2015.12.003

Kanzari F, Syakti SD, Asia L, Malleret L, Mille G, Jamoussi B, Abderrabba M, Doumeng P (2012) Aliphatic hydrocarbons, polycyclic aromatic hydrocarbons, polychlorinated biphenyls, organochlorine, and organophosphorous pesticides in surface sediments from the Arc river and the Berre lagoon, France. Environment Science Pollution Research 19(2):559-576. DOI: http://dx.doi.org/10.1007/s11356-011-0582-5

Klosterhaus SL, Dipinto LM, Chandler GT (2003) Comparative assessment of azinphosmethyl bioaccumulation and toxicity in two estuarine meiobenthic harpacticoid copepods. Environmental Toxicology and Chemistry 22:2960-2968. DOI:

http://dx.doi.org/10.1897/02-411

Kuranchie-Mensah H, Atiemo SM, Palm LMN, BlanksonArthur, S, Tutu AO, Fosu P (2012) Determination of organochlorine pesticide residue in sediment and water from the Densu river basin, Ghana. Chemosphere 86(3):286-292. DOI:

http://dx.doi.org/10.1016/j.chemosphere.2011.10.031

Li J, Li F, Liu Q (2015) Sources, concentrations and risk factors of organochlorine pesticides in soil, water and sediment in the Yellow River estuary. Marine Pollution Bulletin 100(1):516-522. DOI:

http://dx.doi.org/10.1016/j.marpolbul.2015.09.003

Liu M, Cheng S, Ou D, Yang Y, Liu W, Hou L, Gao L, Xu S (2008) Organochlorine pesticides in surface sediments and suspended particulate matters from the Yangtze estuary, China. Environmental Pollution 156(1):168-173. DOI: http://dx.doi.org/10.1016/j.envpol.2007.12.015

Liu W, Wang Y, He W, Qin N, Kong X, He Q, Yang B, Yang C, Jiang Y, Jorgensen SR, Xu F (2016) Aquatic biota as potential biological indicators of the contamination, bioaccumulation and health risks caused by organochlorine pesticides in a large, shallow Chinese lake (Lake Chaohu). Ecological Indicators 60:335-345. DOI: http://dx.doi.org/10.1016/j.ecolind.2015.06.026

Long ER, Macdonald DD, Smith S, Calder FD (1995) Incidence of adverse biological effects within ranges of chemical concentrations in marine and estuarine sediments. Environmental Management 19(1):81-97. DOI: http://dx.doi.org/10.1007/BF02472006

Lozano-Paniagua D, Gomez-Martín A, Gil F, Parrón T, Alarcón R, Requena M, Lacasaña M, Hernández AF (2016) Activity and determinants of cholinesterases and paraoxonase-1 in blood of workers exposed to noncholinesterase inhibiting pesticides. Chemico-Biological Interactions 259:160-167. DOI:

http://dx.doi.org/10.1016/j.cbi.2016.04.008

Macdonald DD, Carr RS, Calder FD, Long ER, Ingersoll CG (1996) Development and evaluation of sediment quality guidelines for Florida coastal waters.

Ecotoxicology 5(4)253-278. DOI:

http://dx.doi.org/10.1007/BF00118995
Masiá A, Vásquez K, Campo J, Picó Y (2015) Assessment of two extraction methods to determine pesticides in soils, sediments and sludges. Journal of Chromatography A 1378:19-31. DOI:

http://dx.doi.org/10.1016/j.chroma.2014.11.079

Montuori P, Aurino S, Garzonio F, Sarnacchiaro P, Polichetti S, Nardone A, Triassi M (2016) Estimates of Tiber River organophosphate pesticide loads to the Tyrrhenian Sea and ecological risk. Science of the Total Environment 559:218-231. DOI:

http://dx.doi.org/10.1016/j.scitotenv.2016.03.156

Oliveira AHB, Cavalcante RM, Duaví WC, Fernandes GM, Nascimento RF, Queiroz MELR, Mendonça KV (2016) The legacy of organochlorine pesticide usage in a tropical semi-arid region (Jaguaribe River, Ceará, Brazil): Implications of the influence of sediment parameters on occurrence, distribution and fate. Science of the Total Environment 542(A)254-263. DOI:

http://dx.doi.org/10.1016/j.scitotenv.2015.10.058

Pandit GG, Sahu SK, Sadasivan S (2002) Distribution of $\mathrm{HCH}$ and DDT in the coastal marine environment of Mumbai, India. Journal Environmental Monitoring 4(3):431-434.

Pejman A, Bidhendi GN, Ardestani M, Saeedi M, Baghvand A (2015) A new index for assessing heavy metals contamination in sediments: A case study. Ecological indicators 58:365-373. DOI: http://dx.doi.org/10.1016/j.ecolind.2015.06.012

Ragab S, Sikaily AE, Nemr AE (2016) Concentrations and sources of pesticides and PCBs in surficial sediments of the Red Sea coast, Egypt. The Egyptian Journal of Aquatic Research 42(4):365-374. DOI:

http://dx.doi.org/10.1016/j.ejar.2016.09.007

Rasmussen JJ, Wiberg-Larsen P, BaattruP-Pedersen A, Cedergreen N, Mcknigth US, Kreuger J, Jacobsen D, Kristensen AE, Friberg N (2015) The legacy of pesticide pollution: an overlooked factor in current risk assessments of freshwater systems. Water Research 84:25-32. DOI: http://dx.doi.org/10.1016/j.watres.2015.07.021

Rodriguéz AGP, Lópes MIR, Cassilas TAD, León AA, Mahjoub O, Prusty AK (2016) Monitoring of organochlorine pesticides in blood of women with uterine cervix cancer. Environmental Pollution 220:853-862. DOI: http://dx.doi.org/10.1016/j.envpol.2016.10.068

Selvaraj KK, Shanmugam G, Sampath S, Larsson DGJ, Ramaswamy BR (2014) GC-MS determination of bisphenol $\mathrm{A}$ and alkylphenol ethoxylates in river water from India and their ecotoxicological risk assessment. Ecotoxicology and Environmental Safety 99:13-20. DOI: http://dx.doi.org/10.1016/j.ecoenv.2013.09.006

Souza DS, Ramos AP, Nunes FF, Moresco V, Taniguchi S, Leal DA, Sasaki ST, Bicego MC, Montone RC, Durigan M, Teixeira AL, Pilotto MR, Delfino N, Franco RM, Melo CM, Bainy AC, Barardi CR (2012) Evaluation of tropical water sources and mollusks in southern Brazil using microbiological, biochemical, and chemical parameters. Ecotoxicology and Environmental Safety 76(2):153-61. DOI: http://dx.doi.org/10.1016/j.ecoenv.2011.09.018 
USEPA - United States Environmental Protection Agency. Toxicity testing and ecological Risk assessment guidance for benthic invertebrates. Available:

http://www.epa.gov/sites/production/files/201508/docume nts/toxtesting_ecoriskassessmentforbenthicinvertebrates.p df. Accessed: Nov 19, 2016.

USGS 2015. Landsat 8 (L8) Data users Handbook. USGS, v1.

VROM - Ministerie Van Volkshuisvesting Ruimtelijke Ordening en Milieubeheer (2000) Dutch Target and Intervention Values, (the New Dutch List). ANNEXES Circular on target values and intervention values for soil remediation. Holanda.

Wang L, Jia H, Xianjie L, Sun Y, Yang M, Wenjun H, Hong Q, Li Y-F (2013) Historical contamination and ecological risk of organochlorine pesticides in sediment core in northeastern Chinese river. Ecotoxicology and Environmental Safety 93:112-120. DOI: http://dx.doi.org/10.1016/j.ecoenv.2013.04.009

Weston DP, Ding Y, Zhang M, Lydy MJ (2013) Identifying the cause of sediment toxicity in agricultural sediments: The role of pyrethroids and nine seldommeasured hydrophobic pesticides Chemosphere 90(3):958964. DOI:

http://dx.doi.org/10.1016/j.chemosphere.2012.06.039
WHO - World Health Organization (1982) Micropollutants in river sediments. World Health Organization. 85p.

Wu C, Zhang A, Liu W (2013) Risks from sediments contaminated with organochlorine pesticides in Hangzhou, China. Chemosphere 90(9):2341-2346. DOI: http://dx.doi.org/10.1016/j.chemosphere.2012.10.023

Wu Q, Leung JY, Yuan X, Huang X, Li H, Huang Z, Li Y (2015) Biological risk, source and pollution history of organochlorine pesticides (OCPs) in the sediment in Nansha mangrove, South China. Marine Pollution Bulletin 96(1-2):57-64. DOI:

http://dx.doi.org/10.1016/j.marpolbul.2015.05.047

Yohannes YB, Ikenaka Y, Nakayama SMM, Mizukawa H, Ishizuka M (2017) DDTs and other organochlorine pesticides in tissues of four bird species from the Rift Valley region, Ethiopia Science of the Total Environment 574:1389-1395. DOI:

http://dx.doi.org/10.1016/j.scitotenv.2016.08.056

Yuan H, Liu E, Zhang E, Luo W, Chen L, Wang C, Lin Q (2017) Historical records and sources of polycyclic aromatic hydrocarbons (PAHs) and organochlorine pesticides (OCPs) in sediment from a representative plateau lake, China. Chemosphere 173:78-88. DOI: http://dx.doi.org/10.1016/j.chemosphere.2017.01.047 